\title{
Waste Minimization Efforts towards Green Logistic at PT Nardevchem Kemindo
}

\author{
Bernand Setia Agustinus and Tukhas Shilul Imaroh
}

\section{ABSTRACT}

\begin{abstract}
PT Nardevchem Kemindo is a company in the distribution of raw materials for processed food and beverages industries. The problem studied in this research is that during the $2015-2019$ period, the waste level occurs in the company's data always exceeds the company's tolerance limit of $1 \%$ and always increases each year. The purpose of this research is to find out the root cause of the waste and to formulate the improvement recommendations for the company to minimize waste as the company's efforts towards Green Logistics. The methods used in this research is the DMAIC concept, followed by the fishbone to identify the root cause of the problem, and the FMEA followed by the $5 \mathrm{~W}+1 \mathrm{H}$ method to formulate proposed improvements for company. Improvement recommendations for the company are the training for the sales team, installation of air conditioners and thermostat at the warehouse, and formulating SOPs for incoming goods inspection.
\end{abstract}

Keywords: dmaic, fishbone, green logistic, Ishikawa, waste.

\author{
Submitted : June 26, 2021 \\ Published : August 17, 2021 \\ ISSN: $2507-1076$ \\ DOI: $10.24018 / \mathrm{ejbmr} .2021 .6 .4 .992$ \\ Bernand Setia Agustinus* \\ Mercu Buana University, Jakarta, \\ Indonesia. \\ (e-mail: b3rn4nd@hotmail.com) \\ Tukhas Shilul Imaroh \\ Mercu Buana University, Jakarta, \\ Indonesia. \\ (e-mail: ts_imaroh @ ${ }^{\circledR}$ ahoo.com) \\ *Corresponding Author
}

\section{INTRODUCTION}

This era of globalization and information openness makes the competition between companies in the industries stricter. Every company is required to have advantage in the industrial competition. One of the customers' demands currently is the importance of the application of the environmental-friendly concept in the companies and the reduction in pollutant contribution to the environment which comes from the companies' operational activities from upstream to downstream. Industrial developments and consumer's demands have forced the industry to adapt to the environmental-friendly concept which later developed into the concept of Green Logistic as part of Green Supply Chain Management (GSCM). GSCM is the concept of the traditional supply chain management concept which is integrated with the environmental aspects including product design, supplier's selection process, procurement, production, packaging, and distribution to customers.

PT Nardevchem Kemindo is a company which business is in sales of raw materials for processed food industries. This company frequently importing various kinds of raw materials for processed food industries and then distribute it to many manufacturing companies in Indonesia. This company's sales in several years recently consistently increasing each year. Fig. 1 shows sales increase of the company during period of 2015-2019. Even so, the sales target also increased every year. Fig. 1 shows that the gap between sales and target also increased every year.

Along the operations of PT Nardevchem Kemindo, there is always can be found inventory excess that are not sold until those are expired. Those unsold expired inventory excess then will be recorded as waste in the inventory system. The company has internal policy which limit the target of these waste to not exceed one percent of the company's annual sales annually (in terms of quantity). In recent years especially since 2015 , the percentage of these waste always exceeds the expected limit of $1 \%$ of the annual company's sales quantity and always increasing each year. This problem has become the company's concern because it does not only affect the financial situation of the company but also the environment. The data of \%waste of the company's annual sales quantity at PT Nardevchem Kemindo is reflected in Fig. 2.

The aim of this research is to study the main factors of the high waste level in the company and to compile recommendations to the company's management team through Green Logistic concept. Based on previous research by Kaur et al. [1], Teixeira [2] and Sehnem \& Oliveira [3] can be concluded that Green Logistic concept is effective to reduce waste level in company which in the end will benefit the environment.

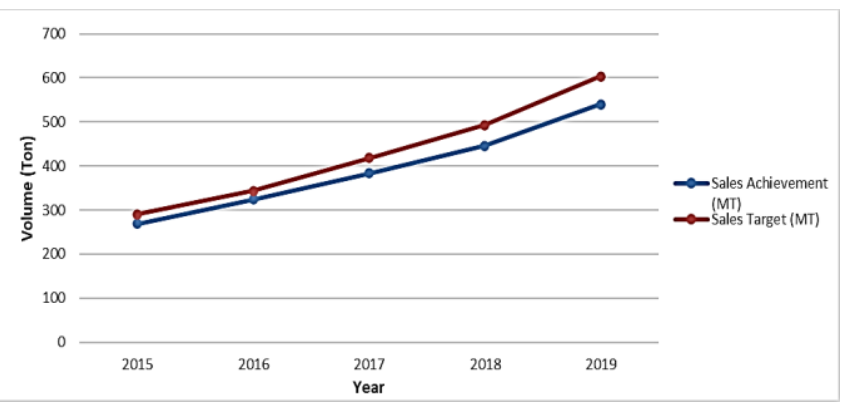

Fig. 1. Sales of PT Nardevchem Kemindo 2015 - 2019. Source: Data compiled. 


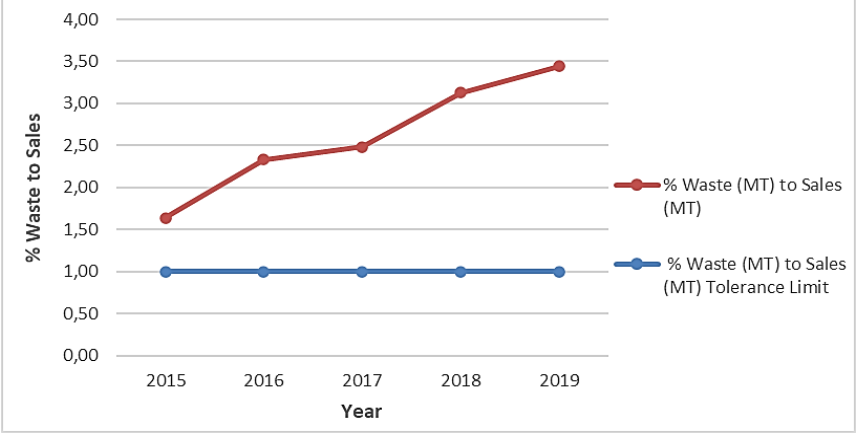

Fi. 2. Percentage of Waste to Annual Sales 2015-2019. Source: Data compiled.

\section{LITERATURE REVIEW}

\section{A. Concept of Waste}

According to Garvin [4] in Gasperz [5], waste can be defined as all activities with no added value in the process of transforming inputs into outputs along the value stream mapping. In other words, waste includes all activities, goods and other things along the process that added no value to the whole system.

\section{B. Supply Chain Management}

According to Siahaya [6], Supply Chain Management (SCM) carries out flow of activities ranging from material raw (upstream) into the hands of consumers (downstream), a process that includes planning, purchasing, storage, up to transport and distribution. While according to Holcomb [7] is an implementation of the orientation of the supply chain in the form of planning and management of all the activities that are involved in resources and procurement, conversion, and all the activities of the logistics management, which involves a process of coordination and collaboration with business partners such as supplier, third party service providers, and customers.

\section{Green Supply Chain Management}

The concept of Green Supply Chain Management (GSCM) is a form of integration of the principles "Green", the environmentally friendly of the whole chain in Supply Chain Management (SCM). Blanchard [8] defines Green Supply Chain Management (GSCM) as a reference to the alignment between the sourcing of raw material, manufacturing, distribution, transportation, and process of remanufacturing/ recycling with the purpose of correcting the effects of the performance of the company towards the environment. Meanwhile according to Diabat [9], Green Supply Chain Management (GSCM) is the process of incorporating environmental criteria into company decisions in purchasing and long-term relationships with suppliers. At its core the concept of Green Supply Chain Management (GSCM) is how the alignment process of material raw to get into the consumer has indicated positive towards the environment.

\section{Green Logistic}

Green Logistics is part of the Green Supply Chain Management. According to Saroha [10] in Kaligis et al. [11], Green Logistics is a form of logistics which is environmentally friendly. According to Sabina [12] in Kaligis [11], Green Logistic should include green management, green information system, green supply, green production, green packaging, green distribution processing and waste recycling.

\section{E. DMAIC Concept}

According to Chase [13], DMAIC (Define-MeasureAnalyse-Improve-Control) is a method that is used to measure the application of Six Sigma which consists of five stages, namely define, measure, analyse, improve, and control.

\section{F. Fishbone Diagram/Cause and Effect Diagram}

Fishbone diagram is an analysis method invented by Kaoru Ishikawa to identify the cause and consequence of a problem. The main branch at the diagram indicates the problems, while other branches coming from the main branch is the cause of the problems which are usually categorized into people, materials, equipment, management, and environment. Fishbone diagrams are very useful in the quality improvement due to its ability to visualize the roots of the problem in simple way [14] as shown in Fig. 3.

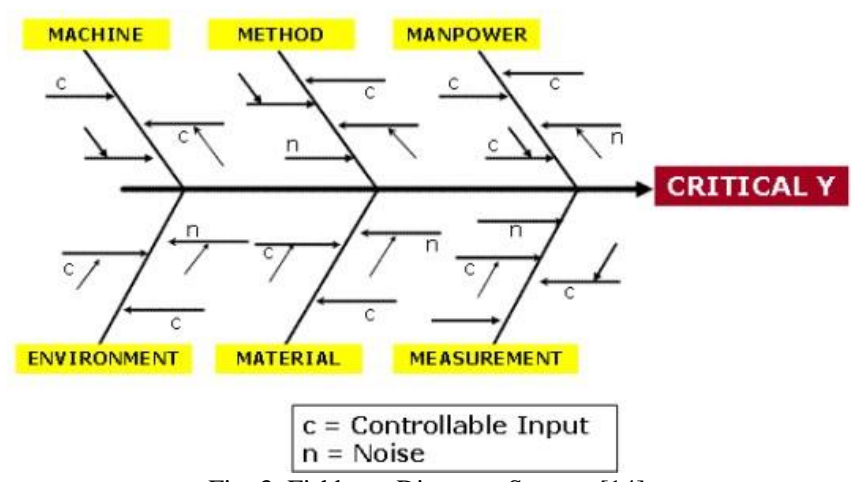

Fig. 3. Fishbone Diagram. Source: [14].

\section{RESEARCH METHODS}

This study aims to explain the phenomena that occur through the descriptive explanatory research design. The phenomenon in this research is the percentage of waste that always exceeds the limits of tolerance of the company of $1 \%$ and the increasing trend each year during the period 20152019. While the variable in this research is shown in Table I.

\begin{tabular}{ccccc}
\multicolumn{4}{c}{ TABLE I: OPERATIONALIZATION OF VARIABLES } \\
\hline \multirow{2}{*}{ Variable } & \multirow{2}{*}{ Dimension } & Indicator & $\begin{array}{c}\text { Type of } \\
\text { Data }\end{array}$ & $\begin{array}{c}\text { Source of } \\
\text { Data }\end{array}$ \\
\hline \multirow{3}{*}{ Cause of } & \multirow{2}{*}{ Defect } & Man & Primary & Informant \\
Waste & & Machine & Primary & Informant \\
& & Method & Primary & Informant \\
& & Material & Primary & Informant \\
& & Environment & Primary & Informant \\
\hline
\end{tabular}

Source: Data compiled.

The population in this study is all waste data and sales data of all products at PT Nardevchem Kemindo. Data sampling for research using nonprobability sampling with purposive sampling technique. In this study, the sample drawn from the population is data on waste and sales of powdered cheese and olive oil products at PT Nardevchem Kemindo. Product of cheese powder and oil of olive is two products which dominate both in terms of sales and waste quantities.

In this study, the method used to collect the data is through the Focus Group Discussion (FGD) in the analysis process by 
inviting the key informants to discuss some concepts together to avoid subjectivity and biased perception in the search for the root cause of the problem.

The following are the analysis stages in this research:

Define - at this step, the problem of the research is formulated or defined which is the waste level of the company that always exceeds the $1 \%$ company's limit and always increasing each year.

Measure - this step includes the data measurement which in this research are the waste dan sales data of the company and the percentage of the waste level to the sales total.

Analyze - this stage includes root cause analysis and cause-and-effect diagram or fishbone diagram to determine the root of the problem of waste and the cause of the occurrence of waste in the company. The results of the fishbone diagram analysis will then be processed for further analysis with Failure Mode and Effects Analysis (FMEA). From the results of FMEA analysis, the most dominant root cause of the problem will be shown. The data processed in the stage of this analysis is comprised of severity, occurrence, and detection which were conducted by sending questionnaire to the respondent who has been through the process of FGD (focus group discussion) while determining the root of the problem in the fishbone diagram analysis. Value of the severity is determined by how big the potentials of the failure are. While the value of the occurrence is determined from how often the failure will appear. The value of the detection is determined by how difficult the failure can be detected. The value ranging from 0-10. After determining the value of these 3 factors, then followed by determining the value of the RPN (Risk Priority Number). RPN calculation is obtained from the multiplication of severity, occurrence, and detection. The higher the RPN value means the higher the risk of the failure, so that the failure of these should be immediately corrected.

Improve - at this stage the recommendations for improvement are formulated based on the dominant root causes as the results from the FMEA analysis. Methods used in this stage is $5 \mathrm{~W}-1 \mathrm{H}$, namely: What, what are the target of a major on the improvement of the quality? Why, why is an action plan needed? Where, where will the plans be implemented? Who, who are going to work on the activity plan? When, when will this action be carried out? How, how do we plan it?

Control - this stage includes setting the instrument for monitoring and controlling to keep the company to always meets the standards that have been set, namely the percentage of waste on sales that do not exceed the level of $1 \%$.This research will describe the causal correlation between the variables through hypothesis test, namely the hypothesis test which according to the theory that has been formulated previously then the data obtained will calculated with quantitative method [15].

\section{FINDINGS AND DISCUSSION}

Data in this study processed through the method of DMAIC (define, measure, analyze, improve dan control) and the results are as the following:

Define - the logistic process at PT Nardevchem Kemindo as shown in Fig. 4. In the process of storage inventory at the warehouse, should be noted that each good that are imported and then stored at the warehouse of PT Nardevchem Kemindo has certain shelflife period. Goods which have exceeded the shelflife period during storage and still unsold will be destroyed and recorded as waste. The company has an internal policy that limit the target of waste are expected to not exceed $1 \%$ of the quantity of sales. While in recent years, especially since 2015 the amount of this type of waste always exceeds the limit of $1 \%$ of the total quantity of annual sales. This is a main concern of management because apart from contributing to the company's operational cost, such waste also has the potential to become a source of environmental pollution.

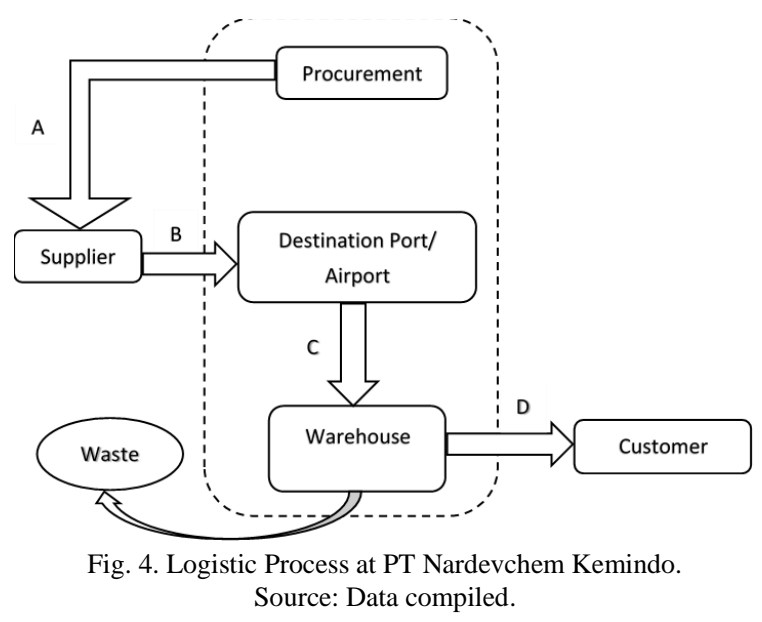

Measure - this stage includes the measurements of the company's waste data (both value and quantity of waste), also as percentage of the total sales of the products of the company. Waste data of PT Nardevchem Kemindo as in volume and value of products that are unsold until exceeded the product's shelflife are presented in Table II. Meanwhile Table 3 shows the annual sales volume and value during the 2015-2019 period. The percentage of waste to annual sales compared to the company's tolerance limit for waste is shown in Table IV.

TABLE II: WASTE DATA OF PT NARDEVCHEM KEMINDO

\begin{tabular}{ccc}
\hline Sales Year & Waste Quantity (MT) & Waste Value (USD) \\
\hline 2015 & 4.4 & 25.725 \\
2016 & 7.57 & 36.700 \\
2017 & 9.53 & 59.305 \\
2018 & 13.95 & 84.825 \\
2019 & 18.57 & 106.600 \\
\hline
\end{tabular}

Source: Data compiled.

TABLE III: SALES DATA OF PT NARDEVCHEM KEMINDO

Sales Year $\quad$ Waste Quantity (MT) Waste Value (USD)

$\begin{array}{lcc}2015 & 268.6 & 1719750 \\ 2016 & 324.45 & 2156500\end{array}$

$\begin{array}{lll}2016 & 324.45 & 2156500\end{array}$

$2017 \quad 383.7 \quad 2618750$

$2018 \quad 446.25 \quad 3085750$

$2019 \quad 539.6 \quad 3742000$

Source: Data compiled.

TABLE IV: DATA OF \% WASTE TO SALES AT PT NARDEVCHEM KEMINDO

\begin{tabular}{ccc}
\hline Sales Year & Waste Quantity (MT) & Waste Value (USD) \\
\hline 2015 & 1.64 & 1 \\
2016 & 2.33 & 1 \\
2017 & 2.48 & 1 \\
2018 & 3.13 & 1 \\
2019 & 3.44 & 1 \\
\hline
\end{tabular}

Source: Data compiled. 
As seen from the data that there is a phenomenon of waste in the form of products of companies that remains unsold until exceeds the product's shelf life that every year experiencing an increase in volume and value, including the percentage of the volume and value of the annual sales. Thus, it becomes the variable that will be analyzed to find the root of the problem and to formulate the recommendations for improvement.

Analyze - this stage includes the making of the root cause analysis and cause-and-effect diagram or fishbone diagram to determine the root cause of the problem of waste and the root cause of the occurrence of waste that exceeds the limits of tolerance of the company. The results of the data collection using the FGD (focus group discussion) method is shown in the fishbone diagram in Fig. 5.

Improve - at this stage the weighting of severity, occurrences, and detection in the FMEA follow-up analysis is obtained from the recapitulation of questionnaires to the key informant from the FGD process at the fishbone diagram analysis stage. Here are shown Table $\mathrm{V}$ the results of analysis FMEA by calculating the value of the RPN or the value of the priority the settlement of the problem.

Based on Table $\mathrm{V}$ can be seen that there are potential risks that can cause the waste level to keep increasing and exceeding the company's limit. Out of all the failure's cause shown in Table $\mathrm{V}$, there are three main issues as the biggest contributor to the waste problem as shown in Table VI.

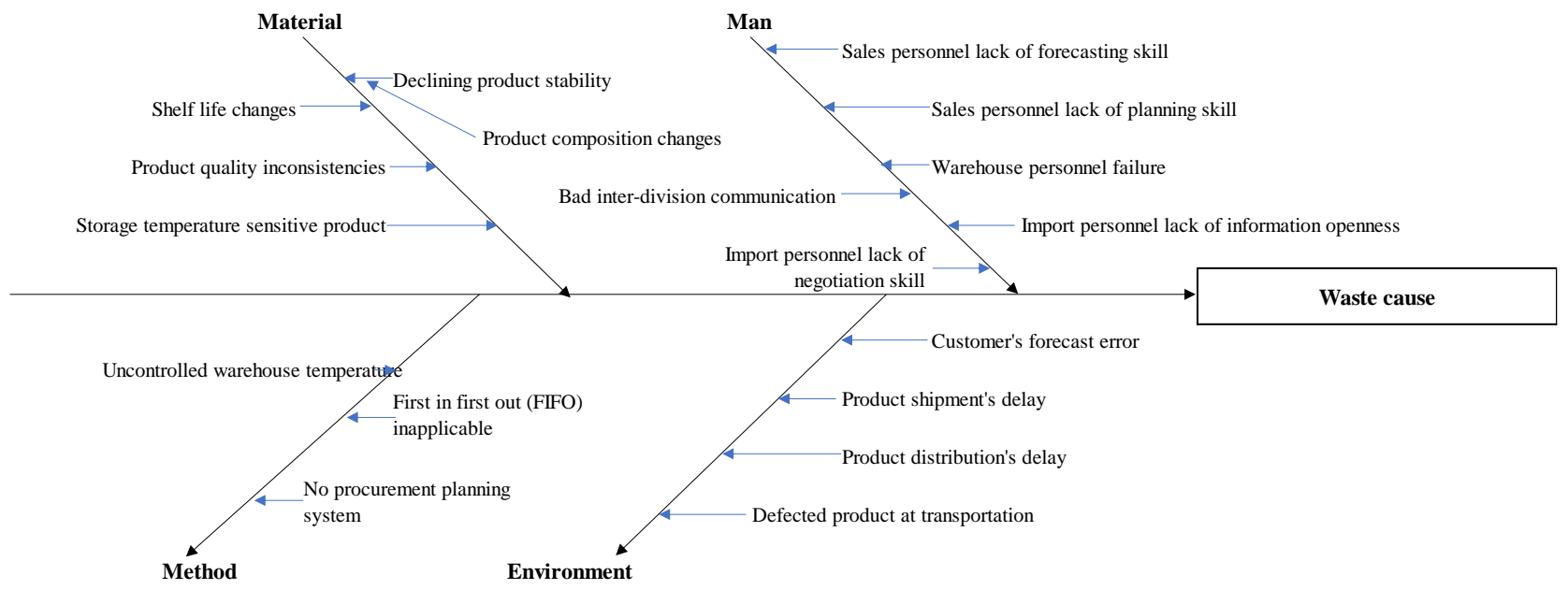

Fig. 5. Fishbone Diagram of the Waste Cause at PT Nardevchem Kemindo. Source: Data compiled.

TABLE V: FAILURE MODE EFFECT ANALYSIS (FMEA)

\begin{tabular}{|c|c|c|c|c|c|c|c|}
\hline \multicolumn{8}{|c|}{ Failure Mode Effect Analysis (FMEA) worksheet } \\
\hline Problem & Factor & Cause of Failure & Failure's Effect & Severity & Occurences & Detection & RPN \\
\hline \multirow{17}{*}{$\begin{array}{l}\text { Waste } \\
\text { Cause }\end{array}$} & Material & Product composition changes & Defected product & 3 & 7 & 2 & 42 \\
\hline & & Declining product stability & Defected product & 5 & 5 & 3 & 75 \\
\hline & & Product quality inconsistencies & Rejected product & 6 & 5 & 4 & 120 \\
\hline & & $\begin{array}{l}\text { Storage temperature sensitive } \\
\text { product }\end{array}$ & $\begin{array}{l}\text { Product defect } \\
\text { before expired }\end{array}$ & 5 & 6 & 3 & 90 \\
\hline & & Shelflife changes & $\begin{array}{l}\text { Product defect } \\
\text { before expired }\end{array}$ & 5 & 8 & 2 & 80 \\
\hline & Man & $\begin{array}{l}\text { Sales personnel lack of } \\
\text { forecasting skill }\end{array}$ & Excess inventory & 7 & 4 & 7 & 196 \\
\hline & & Warehouse personnel failure & Defect packaging & 8 & 3 & 4 & 96 \\
\hline & & $\begin{array}{l}\text { Import personnel lack of } \\
\text { information openness }\end{array}$ & Import delay & 4 & 3 & 5 & 60 \\
\hline & & $\begin{array}{l}\text { Import personnel lack of } \\
\text { negotiation skill }\end{array}$ & Import delay & 4 & 4 & 5 & 80 \\
\hline & & $\begin{array}{c}\text { Bad inter-division } \\
\text { communication }\end{array}$ & Import delay & 3 & 2 & 6 & 36 \\
\hline & Method & $\begin{array}{l}\text { Uncontrolled warehouse } \\
\text { temperature }\end{array}$ & $\begin{array}{l}\text { Product defect } \\
\text { before expired }\end{array}$ & 8 & 7 & 3 & 168 \\
\hline & \multirow{6}{*}{ Environment } & $\begin{array}{l}\text { First in first out (FIFO) } \\
\text { inapplicable }\end{array}$ & Excess inventory & 3 & 4 & 2 & 24 \\
\hline & & No procurement planning system & Excess inventory & 5 & 3 & 2 & 30 \\
\hline & & Customer's forecast error & Excess inventory & 5 & 3 & 5 & 75 \\
\hline & & Product shipment's delay & Excess inventory & 3 & 2 & 4 & 24 \\
\hline & & Product distribution's delay & Excess inventory & 3 & 3 & 4 & 36 \\
\hline & & $\begin{array}{l}\text { Defected product at } \\
\text { transportation }\end{array}$ & Defect packaging & 7 & 4 & 2 & 56 \\
\hline
\end{tabular}

Source: Data compiled.

TABLE VI: RISK RANK BASED ON RPN VALUE

\begin{tabular}{cccc}
\hline No & Cause of Failure & RPN & Rank \\
\hline 1 & Sales personnel lack of forecasting skill & 196 & 1 \\
2 & Uncontrolled warehouse temperature & 168 & 2 \\
3 & Product quality inconsistencies & 105 & 3 \\
\hline
\end{tabular}

Source: Data compiled.
The next step is to compile the recommendation of improvement plans to handle the waste problem based on the result of FMEA analysis. Those three main risks causing the problem shown in Table VI will be analyzed through $5 \mathrm{~W}-1 \mathrm{H}$ (what, why, where, when, who and how) to determine the 
improvement plans that will be recommended to the company's management to solve the waste problem. Results of $5 \mathrm{~W}-1 \mathrm{H}$ analysis can be seen in Table VII.

\begin{tabular}{|c|c|c|c|}
\hline Cause of Failure & $5 \mathrm{~W} 1 \mathrm{H}$ & Definition & Description \\
\hline \multirow{6}{*}{$\begin{array}{l}\text { Sales personnel } \\
\text { lack of } \\
\text { forecasting skill }\end{array}$} & What & $\begin{array}{l}\text { What is the } \\
\text { improvement plan }\end{array}$ & $\begin{array}{l}\text { Training to improve } \\
\text { sales skills }\end{array}$ \\
\hline & Why & $\begin{array}{l}\text { Why improvement } \\
\text { should be made }\end{array}$ & $\begin{array}{l}\text { To minimize waste } \\
\text { level due to lack of } \\
\text { sales skills }\end{array}$ \\
\hline & Where & $\begin{array}{l}\text { Improvement } \\
\text { location }\end{array}$ & Office \\
\hline & When & Improvement time & January 2022 \\
\hline & Who & Improvement PIC & HR Department \\
\hline & How & $\begin{array}{l}\text { How the plan will be } \\
\text { implemented }\end{array}$ & $\begin{array}{c}\text { Organize the sales team } \\
\text { training }\end{array}$ \\
\hline \multirow{6}{*}{$\begin{array}{l}\text { Uncontrolled } \\
\text { warehouse } \\
\text { temperature }\end{array}$} & What & $\begin{array}{l}\text { What is the } \\
\text { improvement plan }\end{array}$ & $\begin{array}{c}\text { Installation of AC and } \\
\text { thermostat at the } \\
\text { warehouse }\end{array}$ \\
\hline & Why & $\begin{array}{l}\text { Why improvement } \\
\text { should be made }\end{array}$ & $\begin{array}{l}\text { Maintain the product } \\
\text { quality to reduce } \\
\text { product defect before } \\
\text { expiry date }\end{array}$ \\
\hline & Where & $\begin{array}{l}\text { Improvement } \\
\text { location }\end{array}$ & Warehouse \\
\hline & When & Improvement time & July 2021 \\
\hline & Who & Improvement PIC & Warehouse manager \\
\hline & How & $\begin{array}{l}\text { How the plan will be } \\
\text { implemented }\end{array}$ & $\begin{array}{l}\text { Installation of AC and } \\
\text { thermostat at the } \\
\text { warehouse }\end{array}$ \\
\hline \multirow{6}{*}{$\begin{array}{l}\text { Product quality } \\
\text { inconsistencies }\end{array}$} & What & $\begin{array}{l}\text { What is the } \\
\text { improvement plan }\end{array}$ & $\begin{array}{l}\text { Quality inspection at } \\
\text { incoming products }\end{array}$ \\
\hline & Why & $\begin{array}{l}\text { Why improvement } \\
\text { should be made }\end{array}$ & $\begin{array}{c}\text { To reduce defect from } \\
\text { nonconform product } \\
\text { quality }\end{array}$ \\
\hline & Where & $\begin{array}{l}\text { Improvement } \\
\text { location }\end{array}$ & Warehouse \\
\hline & When & Improvement time & July 2021 \\
\hline & Who & Improvement PIC & Warehouse manager \\
\hline & How & $\begin{array}{l}\text { How the plan will be } \\
\text { implemented }\end{array}$ & $\begin{array}{l}\text { Formulate SOP on } \\
\text { incoming product } \\
\text { quality inspection }\end{array}$ \\
\hline
\end{tabular}

Source: Data compiled.

The waste problem root cause as found in the analysis process are as the following:

The sales team lack of forecasting skills. As for this problem, the improvement action plan recommendation to fix the problem based on $5 \mathrm{~W} 1 \mathrm{H}$ analysis is by organizing sales skills training for sales team by the HR (human resources) department especially to improve the sales team's forecasting skills. The uncontrolled warehouse temperature. As for this problem, the improvement action plan recommendation to fix the problem based on $5 \mathrm{~W} 1 \mathrm{H}$ analysis is by installing AC (air conditioner) and thermostat at the warehouse as surveillance and control instrument supervised by the warehouse manager. The product quality inconsistencies. As for this problem, the improvement action plan recommendation to fix the problem based on $5 \mathrm{~W}-1 \mathrm{H}$ analysis is by formulating SOP (standard operational procedure) for incoming product quality inspection, conducted by the warehouse manager.

\section{CONCLUSION AND RECOMMENDATION}

Main point can be concluded from this research is that the main root cause of the waste problem at PT Nardevchem Kemindo are the sales team lack of forecasting skills, the uncontrolled warehouse temperature, and the product quality inconsistencies. As recommendations for improvement plan at PT Nardevchem Kemindo to fix the waste problem are by organizing sales skills training for sales team by the HR (human resources) department especially to improve the sales team's forecasting skills, installing AC (air conditioner) and thermostat at the warehouse as surveillance and control instrument supervised by the warehouse manager, and formulating SOP (standard operational procedure) for incoming product quality inspection, conducted by the warehouse manager. As recommendations for future further research, the control stage of DMAIC can be done to study the improvement effect of this research to the company's output and waste reduction thus to the environment.

\section{REFERENCES}

[1] Mann, B. J. S., Kaur, H. 2020. "Sustainable Supply Chain Activities and Financial Performance: An Indian Experience”. Vision. Vol. 24(1), pp. 60-69.

[2] Teixeira, C., Assumpção, A., Correa, A., Savi, A., Prates, G. 2018. "The Contribution of Green Logistics and Sustainable Purchasing for Green Supply Chain Management". Independent Journal of Management \& Production.

[3] Sehnem, S., \& Oliveira, G. P. D. (2016). Green Supply Chain Management: an analysis of the supplier-agro industry relationship of a Southern Brazilian company. BBR. Brazilian Business Review, 13, pp. 158-190.

[4] Garvin, David A. 1988. Managing Quality: The Strategic and Competitive Edge. New York.

[5] Gasperz, V. 2013. All in One 150 Keys Performance Indicator and Balanced Scorecard, Malcom Baldrige, Lean Six Sigma Supply Chain Management. Tri-Al-Bros Publishing: Bogor.

[6] Siahaya, W. 2015. Sukses Supply Chain Management: Akses Demand Chain Management. Penerbit In Media: Bogor.

[7] Holcomb, M. 2011. "Challenges and Opportunities in Global Supply Chain Integration, Managing Global Supply Chain Relationships: Operations, Strategies and Practices”. IGI Global, pp. 99-134.

[8] Blanchard, D. 2010. Supply Chain Management Best Practices Second Edition. Hoboken. John Wiley \& Sons Inc: New Jersey.

[9] Diabat, A., Govindan, K. (2011). An analysis of the drivers affecting the implementation of green supply chain management. Resources, Conservation and Recycling.

[10] Saroha, R., 2014, Green Logistics and its significance in modern day systems, International Review of Applied Engineering Research, No.4, Vol. 1, pp. 89-92.

[11] Kaligis, S., R., Satikens, R., E., Opit, P., F. 2018." Studi Mengenai Penerapan Green Logistics dalam Penanganan Limbah Sisa Ikan di TMP Tumumpa”. Jurnal Ilmiah Realtech. Vol. 14(2), pp. 138-142.

[12] Sabina, N., 2012, Reverse Logistics and Green Logistics: a comparison between Wärtsilä and IKEA, Internasional Business.

[13] Chase, R., B., Jacobs, F., R. 2011. Operations and Supply Chain Management. McGraw-Hill/ Irwin:New York.

[14] Lighter, D., E., Fair, D., C. (2004). Principles and Methods of Quality Management in Healthcare. Jones and Bartlett Learning, Sadbury.

[15] Sugiyono. (2011). Memahami Penelitian Kaulitatif. Penerbit Alfabeta, Bandung. 